\title{
Cities of God in northern Asia minor: Using Stark's social theories to reconstruct Peter's communities
}

\author{
Author: \\ Mark W. Wilson ${ }^{1}$

\section{Affiliation:} \\ ${ }^{1}$ Research Fellow, \\ Department of Old \\ Testament and Ancient \\ Near Eastern Studies, \\ University of South Africa, \\ South Africa

\section{Correspondence to:} \\ Mark Wilson \\ Email: \\ markwilson@ \\ sevenchurches.org

\section{Postal address:} \\ PO Box 64788, Virginia \\ Beach, VA 23467, \\ United States of America \\ Dates: \\ Received: 24 July 2010 \\ Accepted: 09 Dec. 2010 \\ Published: 04 Mar. 2011 \\ How to cite this article: \\ Wilson, M.W., 2011, 'Cities \\ of God in northern Asia \\ minor: Using Stark's social \\ theories to reconstruct \\ Peter's communities', \\ Verbum et Ecclesia 32(1), \\ Art. \#422, 9 pages. \\ doi:10.4102/ve.v32i1.422
}

(C) 2011. The Authors. Licensee: OpenJournals Publishing. This work is licensed under the Creative Commons Attribution License.
This article used seven hypotheses from R. Stark's Cities of God (2007) as a heuristic tool to investigate the rise of Christianity in the five Roman provinces mentioned in 1 Peter 1:1. It affirmed that the Christian communities in these provinces were located in an urban, not rural, setting. Building on the research of Hort and Hemer, seven major cities in these provinces were proposed to test Stark's hypotheses with. These cities are Sinope and Amisus in Pontus, Ancyra in Galatia, Caesarea Mazaca in Cappadocia, Dorylaeum in Asia and Nicea and Nicomedia in Bithynia. An important factor noted in several of these cities was their prominence as a commercial seaport and the presence of a Diaspora Jewish community. Utilising this methodological approach helped to elucidate more fully the audience of 1 Peter's geographic and historical background.

\section{Introduction}

In the last decade, Rodney Stark has published two stimulating and controversial titles on early Christianity, The Rise of Christianity (1997) and Cities of God (2007). In these volumes, he applied his training as a sociologist to the vexing issues related to the development of Christianity in the Graeco-Roman world. Stark has sought to supplant the subjective methodology used by many higher critical scholars and has tried to implement an objective methodology that uses scientific method to interpret the historical data instead. Whilst sometimes missing the mark, Stark has, nevertheless, introduced a more controlled way for historians to interpret data that will hopefully result in better research. This article will utilise some of Stark's methodology, especially from his second volume, as a heuristic tool to investigate the rise of Christianity amongst Peter's communities $^{1}$ in Pontus, Galatia, Cappadocia, Asia and Bithynia.

Stark (2007:22) premises his study on a fundamental hypothesis: 'Perhaps the most fundamental Sitz-im-Leben for Christianity was the cities of the Graeco-Roman world of the first several centuries'. This observation is not a new one. Meeks (1981), in a ground-breaking study, The First Urban Christians, advocated that Christianity was essentially an urban movement. Nearly 75 years earlier, Ramsay (1907) had a similar intuition when he named his important study, The Cities of St. Paul. This, of course, contrasts sharply with the view proposed about Peter's audience by Elliott (2000:101) who states: 'The predominantly rural feature of the provinces other than Asia and the absence of any mention of cities point to the rural location of the letter's addressees' ${ }^{2}$

Yet Elliott (2000:91) seems to undermine his own hypothesis by adopting Hort's theory (1898:167-184) of the tentative route taken by Silvanus (or another messenger) in delivering the letter. ${ }^{3}$ This route follows the order of the provinces ${ }^{4}$ mentioned in 1 Peter 1:1 and passes through the major cities of these provinces, starting with Sinope (Hort 1898:176) or Amisus (Hemer 1978:241) and then continuing to Amasia, Caesarea Mazaca and Nicomedia. Seland is pessimistic about the usefulness of the order of the provinces for informing the possible route of a messenger. Because Cappadocia shares no borders with Asia, 'the order of 1 Peter 1:1 is already broken' (Seland 2005:36). This argument has little weight, however, because both Peter and his audience knew the geography of the region and that it was necessary to re-enter Galatia again from Cappadocia in order to reach Asia. To economise language, Peter apparently chose not to repeat Galatia in his list of provinces. The emphasis of Elliott (2000:90) on the 'rural feature' of this route should

1.Hopkins (1998:201) prefers to call these 'house cult-groups', stating that 'the term captures the image of enthusiasm, radicality and fear of persecution which perhaps characterized some early Christian gatherings'.

2.Using a social scientific reading of the text, Elliott derives this interpretation from the designation of the addressees as paroikoi and parepidēmoi (1 Pt 1:1, 17; 2:1). These were persons 'who were actual strangers and resident aliens' (Elliott 1981:63). In his comme tary, Elliot (2000:90) gives two pieces of evidence for this from 1 Peter: the absence of the term ekklesia, which was a basic concept in Paul's urban mission and the prominence given the image of the household. He thus concludes: 'This marks 1 Peter as a notable exception for the generalization that early Christianity everywhere constituted an "urban phenomenon".

3.Elliott (2000:91) mentions other Petrine scholars who have also accepted this theory concerning the route.

4.Green (2007:14) misunderstands Anatolian geography and history when he suggests that 'Peter is referring to five regions rather than five provinces'. 
not necessarily presume only a rural populace, because there were vast expanses of largely uninhabited terrain in this area, even as today. The route suggested by Hort and modified by Hemer has much to commend it, but its weakness is the inclusion of the Pauline cities of Iconium and Pisidian Antioch (cf. Bruce 1992:652) and of the Johannine church of Sardis (cf. Elliott 2000:93 map 3) in southern and western Asia Minor.

Speaking of the evangelisation of north Galatia, Mitchell (1992:871) writes, 'In so far as the gospel was taken here in the early years of the church, the evangelist was the author of 1 Peter'. Michaels (1988:10) also makes an important observation by noting that the provinces listed in 1 Peter 'suggest a route oriented rather toward the Black Sea and centering on northern and eastern churches not reached by the journeys of Paul'. Utilising the insights of Mitchell and Michaels, a modified route after Cappadocia is here proposed (cf. Wilson 2001). From Caesarea Mazaca the messenger turned northwest to the three major cities of north Galatia, Tavium, Ancyra and Pessinus, before passing through the northeast corner of Asia at Dorylaeum and then completing the circle back to Byzantium through Nicea, Nicomedia and Chalcedon. This is the most economical route in terms of land distance from Amisus to Chalcedon, 1347 kilometers. ${ }^{5}$ Seland (2005:36), however, is quite negative about such a proposal, suggesting that 'these areas are so wide that they were hardly possible for one carrier to cover'.

But this conclusion is difficult to sustain because there are a number of ancient precedents for individuals making such a journey. In 14 BC, Herod the Great made a round-trip journey from Jerusalem to Pontus. Although his long sea voyage was delayed by winds, Herod eventually joined Marcus Agrippa, Augustus's son-in-law and supreme commander in the eastern provinces, at Sinope. Josephus describes their journey from Sinope:

Now when they had completed the mission in Pontus on which Agrippa had been sent, they decided not to return by sea; instead, they went successively through Paphlagonia and Cappadocia, and from there traveled overland to Great Phrygia and reached Ephesus.

(Josephus A.J. 16.12.2)

Herod eventually returned to Judea from the nearby island of Samos (Josephus A.J. 16.16-26). Pliny the Younger was dispatched by Trajan from Rome around $110 \mathrm{AD}$ and travelled extensively in Bithynia and Pontus as the legatus Augusti [imperial envoy] for three years. Arrian, born in one of our target cities, Nicomedia, served as governor of Cappadocia from 131 to $137 \mathrm{AD}$ and made a circumnavigation of the Black Sea recorded in his Periplus. The ability of Herod, Agrippa, Pliny the Younger and Arrian to travel by sea and land around Asia Minor, albeit as imperial elites, suggests that it was certainly within the realm of possibility for Peter's messenger to travel similarly to the Pontic coast and then inland. 5.The messenger certainly came by ship from Byzantium and most probably would
have stopped at the Pontian ports of Heraclea, Amastris and Sinope before arriving at Amisus (see Hort 1898:175-76).
To reiterate, the route being proposed goes through cities. With this as a point of departure, we now return to Stark's research. Stark (2007:35-60) has designated 31 cities in 100 $\mathrm{AD}$ as benchmarks for his hypotheses in a chapter called 'The Urban Empire'. Only the major cities of the province of Asia are included in this list, Ephesus, Pergamum and Sardis. Missing are any cities from Pontus, Galatia or Cappadocia. Bithynia might be represented by Byzantium, which is geographically in Thrace, but administratively connected to Bithynia. Pliny the Elder (H.N. 5.143), for example, includes Byzantium in Bithynia.

\section{Stark's seven hypotheses}

To test seven of Stark's hypotheses, seven major cities from the circuit previously suggested have been selected as benchmark cities for this study: Sinope, Amisus, Caesarea Mazaca, Ancyra, Dorylaeum, Nicea and Nicomedia. ${ }^{6}$ By examining these hypotheses in conjunction with the selected cities, the possible location of Peter's communities will be elucidated. In the interest of concision, several of Stark's hypotheses related to a similar subject have been combined under one hypothesis.

\section{Hypothesis 1}

The closer a city was to Jerusalem, the sooner a city had a Christian congregation (Hypothesis 3-2; Stark 2007:77-79)

A common assumption made by some biblical scholars unfamiliar with the topography of Asia Minor is that travel, by Peter or other peripatetic Christian teachers, to cities like Amisus and Sinope from Jerusalem would have been difficult. Jobes (2005:26), for example, states that if Peter did travel to these places, his effort would have to have been quite extraordinary'. From a geographical perspective, Amisus sat at the northern head of the single trans-Anatolian highway that ran from the Mediterranean to the Black Sea (Strabo 14.5.22; Cohen 1996:384). Bryer and Winfield (1985:40) write: 'This is the easiest route from the Pontic coast to the interior of Asia Minor and it must have been an important factor in the growth of Amisos'. In actuality, the distance from Jerusalem to Amisus is 1570 kilometres, which is 245 kilometres $(13 \%)$ shorter than the distance from Jerusalem to Ephesus. ${ }^{7}$ Completing this latter itinerary was apparently so routine that Luke uses only two verses to describe Paul's trip to Ephesus in Acts 18:23 and 19:1. It is possible then that Amisus had a Christian community around the same time as Ephesus, since Jews from both Pontus and Asia are mentioned in the audience on the day of Pentecost (Ac 2:9). In conclusion, it seems better to link Stark's hypothesis not so much to proximity to Jerusalem but to accessibility. And all seven cities under discussion were indeed accessible to Jerusalem by land and sea.

6.Mitchell (1995:243-244 n. 10) estimates that there were about around 130 cities in northern Asia Minor around $A D$ 150. In our specific provinces Pontus had 11; in Cappadocia had only two cities, Caesarea Mazaca and Tyana.

7.The distances were measured on the Barrington Atlas of the Classical World (Talbert 2007) using a Brunton Digital Map Measurer. The distances are over $95 \%$ accurate. Higher accuracies are difficult because of the page creases and the way the maps overlap in the atlas. 


\section{Hypothesis 2}

Hellenic cities had Christian congregations sooner than Roman cities did (Hypothesis 3-3; Stark 2007: 79, 81)

The provinces mentioned in 1 Peter 1:1 were mixed, with regards to their degree of Hellenisation. In his important study, Hellenistic settlements in Europe, the islands, and Asia Minor, Cohen (1996) catalogs the sites of later Hellenistic foundations in Asia Minor. Regarding such sites, he lists five in Pontus, none in Galatia, three in Cappadocia, forty in Asia and ten in Bithynia. Why were there so many foundations during this period? Højte (2009:97) cites the reason: 'A common trait of all Hellenistic kings was their desire to found cities in their own or a family member's name'. However, Sinope and Amisus could claim even earlier foundations as Hellenic poleis (cities). In 631 BC, Sinope became the first of many colonies established by settlers from Miletus (Xenophon An. 6.1.15; Diodorus 14.31.2; Arrian Peripl. M. Eux. 14.5). Nevertheless, there was a lot of confusion related to the foundation date of the city (Tsetskhladze 2007:165-166). Not until 63 BC did Sinope became a Roman colony that was a free and autonomous city called Colonia Iulia Felix Sinope. Thus, in the 1st century AD, Sinope's foundation as a Roman city was only a century old while it had had a 500 year history as a Greek city first. A foundation tradition for Amisus describes its settlement by Milesians in the 6th century BC (Strabo 12.3.14; Tsetskhladze 2007:168-69). Then in the middle of the 5 th century BC, a group of Athenians settled in Amisus (Plutarch Luc. 19.6; Appian Mith. 8, 83; Arrian Peripl. M. Eux. 15.3) and it soon became a free citystate (Wilson 1960:194-95). During Julius Caesar's rule, Roman settlers were integrated into the constitution of the Greek city (Mitchell 1993:1.37) and it became the capital of Roman Pontus. Jobes (2005:20-21) observes that in Pontus 'Hellenized urban centers were few and far between' and that 'Greek or Latin was spoken only by administrative officials'. However, the picture seems much different. As Magie (1950:1.182) notes, 'from the seventh century onward, the influence of Hellenism had been dominant'.

Ancyra never was Hellenised, but remained only a fortress. Such defining characteristics of Hellenisation, public buildings, inscriptions and coinage, are all absent from the settlement until the Roman period (Mitchell 1993:1.81, 85-86). In $25 \mathrm{BC}$, Amyntas bequeathed his kingdom to Rome and Ancyra became the capital of the province of Galatia. In 25 AD, an imperial cult temple for Rome and Augustus was built in the city (Price 1984:267-268).

Caesarea Mazaca was not given the name Caesarea until 12-9 BC, when Archelaus renamed the city; before that it was known as Eusebeia near Argaios (Strabo 12.2.7). The Cappadocian king, Ariarathes V Eusebes Philopator (163-130 BC), well known as a philhellene, founded it as a Greek city in the 2nd century BC. Ariarthes gave Eusebeia a Greek constitution and promoted Greek games (Mitchell 1993:1.81, 82; Cohen 1996:377).
Although no direct evidence exists that Dorylaeum was the site of a Greek city, it has been suggested that a Macedonian colony was planted there by Antigonos. An inscription from the imperial period with the Macedonian name Diophanes, son of Arrhidaios, seems to substantiate that suggestion (Cohen 1996:299). Dorylaeum became part of the Roman province of Asia in 133 BC, when Attalus III bequeathed his kingdom to Rome. Nicea was founded by Antigonus as Antigoneia and renamed Nikaia by Lysimachus for his wife, probably after the battle of Ipsus (301 BC). Although the Bithynian kings took control of the city in 282 or $281 \mathrm{BC}$, the continued presence of Macedonian colonists preserved its Hellenic nature. The names of three of its tribes are known. Both Nicea and Nicomedia came under Roman rule in 74 BC, when Nicomedes III bequeathed his kingdom. In 63 BC, Pompey the Great united coastal Pontus with Bithynia to form a single senatorial province. However, each part of this twin province always retained its distinct identity. In the 1st century BC, Nicea became the second city of Bithynia, the result of a transformation 'from a Hellenistic backwater into one of the major cities of Asia Minor ...' (Mitchell 1993:1.160). In 27 BC the Roman senate awarded the city the right to erect a sanctuary where both Dea Roma and Divus Julius could be worshiped by Roman citizens (Dio Cassius 51.20.6). Nicomedia was founded by the Bithynian king, Nicomedes I, around 265 BC, replacing the Greek colony of Astacus. 'It became the chief city of Hellenistic Bithynia' (Mitchell 2003:1043). The city had a boule [council] and was constituted into tribes. When Bithynia became a Roman province, Nicomedia became the provincial capital. In 27 BC it was awarded the neocoros [custodianship] for the temple for Rome and Augustus, where Greeks worshiped the imperial cult in Bithynia (Dio Cassius 51.20.7).

Of the seven cities being surveyed, five were certainly Hellenic cities, one was a probable one and one was not. However, none were founded as Roman cities and they only came under Rome rule at the beginning of the 2nd century BC. All but Dorylaeum served as provincial capitals, colonies, or imperial cult centres. Because of these factors, these cities fall favourably under Stark's suggestion that they should have a Christian church.

\section{Hypothesis 3}

Larger cities had Christian congregations sooner than smaller cities (Hypothesis 3-4; Stark 2007 81-82)

Stark (2007:35-61) identifies 31 cities in the Roman Empire with a population of 30000 people or more, deeming this the minimum size for a city. He rightly states that the actual population of ancient cities is hard to determine and bases his statistics mainly on the monumental studies of Chandler and Fox (1974) and Chandler (1987). ${ }^{8}$ Yet many of his subsequent assertions are highly disputable. He asserts, for example, that in the empire only Rome and Alexandria had a population of more than 150000 inhabitants. Following is a chart of Stark's lists of ancient cities in Asia Minor and the population assigned to them in his two books:

8.For a critique of Chandler, see Pascuiti and Chase-Dunn (2002). 
TABLE 1: The population of ancient cities in Asia Minor according to Stark.

\begin{tabular}{lll}
\hline Cities & Rise of Christianity $^{+}$ & Cities of God $^{-}$ \\
\hline Antioch on the Orontes & 150000 & 100000 \\
Edessa & 80000 & 75000 \\
Nisibis & - & 67000 \\
Pergamum & $120000^{\ddagger}$ & 40000 \\
Ephesus & 200000 & 51000 \\
Sardis & $100000^{5}$ & 100000 \\
Smyrna & 75000 & 90000 \\
Byzantium/Constantinople & - & 36000 \\
\hline
\end{tabular}

${ }^{\dagger}$. In The Rise of Christianity (1997:131-132) Stark presents a list of 20 cities with a population over 40000 plus Athens and Salamis.

${ }^{\ddagger}$, Stark takes his figure from Galen (5.49). Mitchell (1993:244) suggests a figure between 180 000 and 200000 , noting that with Smyrna and Ephesus, it was one of the three largest cities of western Anatolia.

5. Mitchell (1993:244 n. 13) believes that the $60000-100000$ estimate suggested by Hanfmann (1983:146) is generous.

It is apparent that in the decade of research between his books, Stark has downsized his population estimates for all these cities, with the exception of Sardis and Smyrna. One's confidence in the 'scientific' nature of his research is certainly called into question by this notable discrepancy. In fact, any scholar knowledgeable about the cities of Asia Minor would be puzzled by these statistics. That Sardis would be equal in population to Antioch in the 1st century $\mathrm{AD}$ and larger than Smyrna, Pergamum and Ephesus is highly problematic. Gates (2003:383), one of the authorities cited by Stark, estimates a population for Ephesus of 250000 . Therefore, it is imperative to question Stark's judgment and any conclusions he might draw from these statistics.

As noted previously, Stark does not mention any of our seven target cities. One of the only population estimates for northern Asia Minor was published over 70 years ago by Broughton (1938:4.814), who concedes that any general estimate 'will have a very large margin of error and perhaps is foolish to attempt'. ${ }^{9}$ Nevertheless, Broughton (1938:815) suggests that his estimate 'probably errs by being too small'. Interestingly, Mitchell (1993:244 n. 15) confirms Broughton's estimates based on his own calculations. The following chart shows Broughton's area and population estimates of these five provinces during the imperial period.

Where would these 4.6 million people live? Mitchell (1993:1.244) estimates that, while in the Roman world generally a 10:1 ratio existed between rural and city dwellers, for central Asia Minor he estimates a ratio of 8:1 around 150 AD. He further suggests that few cities had a population greater than 25000 inhabitants, with the majority of the cities having 5000-15 000 residents. He places Nicomedia and Ancyra in the first category. Since Amisus and Caesarea were provincial capitals, their population must have approximated 20 000-25000 people. Sinope, Dorylaeum and Nicea probably ranged from 10000 to 20000 inhabitants. Although below Stark's population threshold, these were, nevertheless, the major cities, the metropolises, of northern Asia Minor and undoubtedly where Christian congregations arose in these provinces. These cities held great attraction for the Greeks and Romans who 'regarded the polis and its institutions as the centre of civilized life' (Bekker-Nielsen 2008:45).

9.In the largest commentary on 1 Peter published recently, Elliott (2000:89) is forced to use Broughton's statistics to try to suggest a population in northern Anatolia.
TABLE 2: Broughton's area and population estimates for the provinces of northern Asia Minor.

\begin{tabular}{lll}
\hline Province & Area (square miles) & Estimated Population \\
\hline Pontus & 12225 & 1000000 \\
Galatia & 15625 & 500000 \\
Cappadocia & 33515 & 900000 \\
Phrygian Asia & 17740 & 700000 \\
Bithynia & 18555 & 1500000 \\
\hline Total & $\mathbf{9 7 6 6 0}$ & $\mathbf{4 6 0 0 0 0 0}$ \\
\hline
\end{tabular}

\section{Hypothesis 4}

Port cities were more likely to have temples to Cybele than inland cities and cities with temples to Cybele had Christian churches sooner than those without (Hypotheses 4-1, 4-3; Stark 2007:94-95)

Because the important subject of port cities is mentioned in Hypotheses 4-6, it will be discussed as a subtopic here. Stark has made an important observation in his list of major cities, namely that the majority were ports. Of our seven target cities, four were port cities. Sinope and Amisus were on the Pontus Euxinus, Nicomedia on the Gulf of Astacus and Nicea on the Propontis. Pontus was oriented toward the sea because the coastal Paryadres range made access to the inland difficult, with the result that its major cities were seaports. Sinope, with its two harbours, was the chief port of call on the southern coast of the Euxine (Strabo 12.3.11; Polybius 5.56.5-6; cf. Magie 1950 1:183-184) and therefore has been called the 'Venice of the Euxine' (Bryer \& Winfield 1985:70). That the distance of many places on the coast was measured from Sinope emphasises the importance of its commercial relationships with the western end of the Euxine and with Greece (Robinson 1906a:134-135). Grant (1997:591) notes that Sinope's location on the Black Sea was at the shortest crossing point to the Tauric Chersonese (Crimea) and thus it 'commanded the maritime Black Sea commerce' ${ }^{10}$ Amisus was situated on the eastern side of a wide bay. Although this harbour did not have natural protection like Sinope's, its position at the head of the trans-Anatolia land route caused it to surpass Sinope in commercial importance. Magie (1950:1.186) summarises the situation of these rival harbours: 'although the older city long maintained her supremacy in the carrying-trade of the Euxine, Amisus developed at Sinope's expense'. Thus Amisus, according to Munro (1901:53), was 'the commercial capital of Pontus'. The historical development of this preference is still seen today in the Turkish cities of Samsun and Sinop, the former being the much larger commercial centre. While Nicea may appear to be an inland city, it was situated on the eastern end of the navigable Lake Ascania. Although its port of Cius (modern Gemlik) was approximately 48.3 kilometres west, land transport was required for only 16 kilometres from the western end of Ascania to the Propontis and this over fairly level terrain (Wilson 1960:91). Magie (1950:1.305) describes

10.The further statement of Grant (1997:592), that Sinope 'dominated land routes communicating with the interior of Asia Minor', needs correction. As Leafe (1916:7) explains: 'It was not the terminus of any road, but it was the centre of the coasting trade; and in that sense only it was the terminus of every road that debouched into the Black Sea'. Sinope was never at the terminus of any important Anatolian caravan route and owed its prosperity and influence to its coastal location. 
Nicomedia as having a 'deep-water harbour of unusual excellence' that 'lay at the end of the great trade-route which traversed the whole length of northern Asia Minor from the Propontis to Pontus and Armenia'. Modern Izmit continues to be the most important port on the Sea of Marmara today.

Stark's hypothesis about Cybele temples in relationship to ports must be modified within the context of Asia Minor. The primary worship centre for Cybele worship was in the inland city of Pessinus (Claerhout \& Devreker 2008:46-49, 80, 157-171). Pessinus was located just off the main Roman road that connected Ancyra and Dorylaeum and it is possible that Peter's messenger visited this important city while delivering the letter. Because of the prominence of the cult of Magna Mater in Rome and the long history associated with it, Romans had a great interest in the cult's place of origin (Turcan 1996:35-56). The worship of Cybele spread concentrically from Pessinus. In Roller's map of all the major sites in Anatolia connected with the Phrygian mother goddess, the distribution of the sites is about one-third inland and two-thirds coastal. Of our seven target cities, Sinope, Ankara, Dorylaeum and Nicomedia are included on the map (Roller 1999:ii-iii). Because of the ubiquitous nature of Cybele worship in Asia Minor, it is doubtful whether a significant link can be made with regard to the location of Cybele temples and the spread of Christianity.

\section{Hypothesis 5}

The more Hellenised port cities were more receptive to the worship of Isis than inland cities and cities with temples to Isis had Christian churches sooner than those without (Hypotheses 4-4, 4-5, 4-7; Stark 2007:111, 113)

According the Turcan (1996):

During the third and second centuries BC, we find that the gods of the Delta spread in various sectors of the Hellenic world, mainly in the islands and ports, but also in the interior.

(Turcan 1996:82)

His comment certainly mitigates Stark's blanket assertion that the worship of Isis spread primarily through businessmen trading in the ports of the Graeco-Roman world. No temples to Isis have been discovered at Sinope or Amisus and Tsetskhladze (2007) has stated well the principal reason why:

The continued near impossibility of undertaking archaeological investigation of Greek and local sites along this coast (Pontus), largely...because ancient sites tend to have been overbuilt by modern towns and cities, or are within or beneath military bases.

(Tsetskhladze 2007:161)

This same situation applies to Ancyra, Nicea and Nicomedia, which are also overbuilt by modern cities.

Because of the dearth of archaeological realia [archaeological artifacts], it is necessary to utilise primarily literary, numismatic and epigraphic evidence to examine this hypothesis. ${ }^{11}$ Magie (1953:180-181) notes that good

11.Even within this evidence, Magie $(1953: 181)$ notes: 'In contrast to the comparatively few places for which there is epigraphical evidence for a public cult or private veneration of Isis and Sarapis is the large number of cities whose coins show representations of these deities'. epigraphical evidence exists for an established cult of Sarapis and Isis, or one of them, during the Hellenistic and Roman periods in 29 places in Asia Minor. ${ }^{12}$ This evidence is the mention of a sanctuary, a priest (or priestess), a neokoros, a group of worshippers or a festival. Magie (1953:181) goes on to point out that while there are 'comparatively few places' for which there is epigraphical evidence, there are at least 118 cities whose coins show representations of these deities. However, it must be pointed out that many of these coins date after the 1st century AD. Amongst these are 73 in Asia and 18 in Bithynia-Pontus. Of the 29 cities with inscriptional evidence, 15 (about $50 \%$ ) issued coins with representations of Isis or Sarapis in either the Hellenistic or the imperial period (Magie 1953:182).

An inscription found in Sinope mentions a lady of senatorial rank who was a priestess of the cult of Isis. Coins from the city also bear the likeness of the goddess (Robinson 1906b:268). A tradition preserved by Tacitus (Hist. 4.83-83) and Plutarch (De Is. et Os. 28; De soll. an. 36) states that Isis's consort Serapis had his origin in Sinope (Magie 1950:68). Coins of Amisus of the time of Hadrian show Sarapis seated with the usual standing figure of Isis (Magie 1953:180). At Ancyra there are dedications or inscribed references to 'Lady Isis' (Magie 1953:179). Mitchell (1993:14) accounts for this and the references to numerous other gods in Ancyra because it 'was a cosmopolitan city where no single god seems to have been overwhelmingly prominent'. It is important to point out that 'cosmopolitan' cities were not only located on the sea coast. Magie (1953:178) does concede, however, that '[i]n the interior of Asia Minor there is but little inscriptional evidence for the worship of the Egyptian deities'. At Dorylaeum a coin shows the bust of Serapis on the obverse and a standing figure of Isis on the reverse (Magie 1953:179). At Nicea, from the time of Antonius Pius to Gallienus, there are coins showing Isis as Pelagia. In this pose she is depicted as the one who endowed the sail with wind and also had power over the sea. Magie (1953:166) comments, 'As Isis Pelagia she was frequently represented as holding an inflated sail (and sometimes a part of a ship) and regarded as the especial protectress of mariners'. At Nicea coins also display the busts of Serapis and Isis in a jugate (overlapping) postion. At Nicea's port of Cius, a Feast of Rejoicing (Charmosyna), probably dating from the Hellenistic period, was likewise held in honour of Isis (Magie 1953:176). Pliny (Ep. 10.33.1) records that the temple of Isis (Iseon) was one of the buildings destroyed by fire in Nicomedia around 110 AD. Coins similar to those of Nicea are extant, the only difference being that the busts of Serapis and Isis are facing each other (Magie 1953:176).

In closing this section it is good to heed the cautionary word of Magie (1953):

In spite of the comparatively large agreement between the numismatic and other evidence, it may scarcely be assumed that there was a cult, either public or private, in every city whose issues show representations of the Egyptian deities. Even if some allowance be made for the indubitable loss of coins, it seems

12.Note that Magie (1953:182) qualifies the original number of 37 cities. 
strange that in fourteen cities where there were cults of Isis and Sarapis no coins bearing their likenesses are known. Conversely, it is difficult to believe that each of the long lists of coining cities maintained a cult ... In the great majority of cases, however, where coins appear within a narrow range of emperors or under a single emperor, especially during the third century, when most of the coins were issued, they can hardly be regarded as proof of the existence of an established cult.

(Magie 1953:184)

Given this caution, perhaps the most that can be said for the target cities that only display late evidence for Isis is that, while public worship may not have occurred at a temple or festival, the goddess was undoubtedly known and worshiped privately by some local adherents.

\section{Hypothesis 6}

The closer a city was to Jerusalem, the more likely that city was to have significant Diaspora Jewish communities, which tended to be located in port cities (Hypothesis 5-1, 2; Stark 2007:123)

Under Hypothesis 1, the geographic distance of these cities from Jerusalem was already discussed. Amongst the Jewish witnesses in Jerusalem on the day of Pentecost were pilgrims from three of the provinces mentioned in 1 Peter 1:1, Cappadocia, Pontus and Asia (1 Pt 2:9). This account, describing an event that occurred over three decades earlier, was perhaps drawn from the personal reminiscences of Peter (cf. Lk 1:2-4). Peter as a source is probable, given that he is the dominant figure in the first 12 chapters of Acts. Luke's inclusion of the Jewish communities on the Black Sea's southern shore, according to Bauckham (1995:421), 'would have given the impression that the Diaspora stretched further north than south'. Trebilco (1991:25) concludes that the 'passage provides evidence that Jews were living in the areas in Asia Minor specified' ${ }^{13}$ At the farthest point of Bithynia there is only 2012 kilometres separating Chalcedon from Jerusalem.

Josephus (A.J. 14.10, 185-267; 16.6, 160-78) documents the presence of Jews throughout Asia Minor by the 1st century $\mathrm{BC}$, a population estimated at one million persons (cf. van der Horst 1990:126). The background of this dispersion in Asia Minor during the Hellenistic period is largely unknown. Amongst the reasons for its occurrence were undoubtedly '[d]iscontent with Ptolemaic and Seleucid rule in Palestine, over-population and land shortage and promising commercial prospects' (Smallwood 1981:122). Antiochus III sent 2000 Jewish families to Lydia and Phrygia around 210 $\mathrm{BC}$ to help to stabilise the region (Josephus A.J. 12.147-53). According to Mitchell (1993:1.135), these settlers 'were first and foremost farmers' because the Jews lived outside of cities. At Docimeum they even worked in the marble quarries. Stark's characterisation of Jews clustered in cities along the sea is easily disproven in the context of Asia Minor, because 'in the mid-first century BC, therefore, some of the largest Jewish settlements were in the Phrygian cities, which belonged to the assize district of Apamea' (Mitchell 1993:1.33).

13. However, I do not agree with Trebilco (1991:25) that those listed in Acts 2 are pemanent residents of Jerusalem. I would see them as pilgrims instead.
Although there is no archaeological evidence of synagogue buildings in northern Asia Minor, as Hachlili (1998:26) shows on her map of Diaspora synagogue sites, inscriptions and artifacts attesting to a Jewish presence in the region are extant. ${ }^{14}$ This establishment of a Jewish presence in northern Asia Minor is important because the book of Acts consistently shows Christian evangelisation in the Diaspora beginning with the Jewish community whenever possible (Ac 13:14; $14: 1 ; 19: 8)$.

Acts 18:2 bears specific testimony to Jews in the Black Sea region. At Corinth Paul 'met a Jew named Aquila, a native of Pontus, who had recently come from Italy with his wife Priscilla'. Pontus was the birthplace of Aquila and probably his wife also (Elliott 2000:87). The two became important coworkers with Paul, who shared the trade of tent making with him (Ac 18:3). The couple was obviously still living as Jews, or else they would not have been sent from Rome around $46 \mathrm{AD}$ in the Jewish deportation (Ac 18:2). Philo and Josephus also bear testimony about Jews on the southern Black Sea coast. ${ }^{15}$ Agrippa's alleged letter to Gaius, included by Philo in his Embassy to Gaius (281), reports that there were Jewish colonies in 'the remote corners of Pontus'. Unfortunately, the names of the places are unidentified. Aquila, a Jewish proselyte who later made a literal translation of the Greek Old Testament (200 AD), was from Pontus.

There is no archaeological evidence for Jews in Ancyra. Mitchell (1992:871) writes: 'Within the boundaries of the Roman province of Galatia there is little reliable evidence for Judaism or Christianity in the 1st and 2nd centuries A.D.'. Theodotus of Ancyra, martyred in $303 \mathrm{AD}$, is said to have converted both Jews and pagans in the city (Life of St Theodotus, ch. 3). The earliest attestation for Jews here comes in the 3rd century AD (Mitchell 1982:133, 141, 508-511). Regarding Caesarea Mazaca, there is neither archaeological nor literary evidence for Jews in the city. Nevertheless, Acts 1:9 records that Jews from Cappadocia were present in Jerusalem on the day of Pentecost. Caesarea Mazaca was the likely home of many of these. While there is no archaeological or literary evidence for Jews in Dorylaeum, a large Jewish community did live in Phrygian Asia. The evidence for Jews in Hierapolis, Acmonia, Apamea and Eumenea has been amply documented (Mitchell (1993:2.32-35; Trebilco 1991:58-95). Because of Dorylaeum's strategic position on a junction of five Roman roads, it is likely that a Jewish community also lived in the city. Philo (Leg. 36) mentions that there were Jewish populations with synagogues in Bithynia. A menorah discovered in secondary use within a baptismal pool is the only evidence for a Jewish community in Nicea. Fine and Rutgers (1996:7) date the menorah to the 4th-6th centuries AD, while Barsanti (2003:269) dates it to the end of the 5 th or the beginning of the 6th century. On the marble slab is the longest citation known of a biblical

14.For inscriptions, see Ameling's work (2004) in which three of our target cities are mentioned, Nicea (2004:321-324); Nicomedia (2004:324-332) and Dorylaeum (2004:392-393)

15.Much more evidence exists for the presence of Jewish communities on the north and east coasts; see Levinskaya (1996:229-246) and Gruen (2002:109). 
verse in a Jewish inscription from the Diaspora. It is also the only known example of an inscription containing Psalm 136:25 (135:25 LXX). During the excavation of the theatre at Nicomedia, two stone plaques with menorahs were found. One of the menorah plaques has 12 letters of an inscription. The menorahs are being examined in the laboratory of the Department of Archaeology at Kocaeli University in İzmit at present and remain unpublished. The style of the menorahs suggests a date from the late antique period. ${ }^{16}$

Because the Jewish realia discovered in Asia Minor date centuries after the 1st century, it must be asked whether they have any relevance for interpreting 1 Peter. Biblical texts like Obadiah 20 (6th century BC) and 1 Maccabees 15:23 (2nd century BC) corrobate Josephus and other literary reference that describe the presence of Jews in Asia Minor dating at least to the Persian and Hellenistic periods. Earlier data has undoubtedly been lost because of earthquakes and subsequent rebuilding. Thus, the literary evidence and the later archaeological discoveries suggest that a stable Jewish population should be presumed. Of our seven target cities three had certain Diaspora Jewish communities, one maybe and the other three provide no evidence.

\section{Hypothesis 7}

\section{Cities with a significant Diaspora community were Christianised sooner than other cities (Hypothesis 5-8; Stark 2007:134-136)}

In the following section, we will trace the rise of Christianity in the target cities. Bryer and Winfield (1985:71) suggest that the origins of Christianity in Sinope date from Trajan's reign and a local tradition places the martyrdom of St. Phokas of Sinope during the time that he reigned. But this is surely too late. The Jewish couple Aquila and Priscilla had probably become Christians in this Roman colony before leaving Pontus for Rome (Ac 18:1). The heretic Marcion (ca. 110-160) was from Sinope (Eusebius Hist.eccl. 4.23.185-186). Hippolytus states that his father was the bishop of the church in the city (Haer.7:17). At Amisus, Bryer and Winfield (1985:92) believe that the city 'certainly had Christians from an early period'. They cite a tradition that Amisus was one of the places supposedly evangelised by St. Andrew. Two authors, writing in the late 2nd century, describe Christian activity in the region. Dionysius, bishop of Corinth, wrote a letter to 'the church sojourning in Amastris, together with the churches in Pontus' (Eusebius, Hist.eccl. 4.23.6), while Lucian (Alex. 25.38) stated that Christians were numerous in Pontus.

Pliny the Younger served as a legatus Augusti in BithyniaPontus from approximately 109-111 AD. Book 10 of his Letters covers his correspondence written during this period. Letters 96-97 are an exchange between Pliny and Trajan regarding the situation of Christians under his jurisdiction. This conflict with the Christians can be dated to his second year in office, between September 18 and New Year, as a result of the serial photographs of menorahs discovered at Sardis, Priene, Andriace and Aphrodisias prompts this suggestion. order of the letters. Sherwin-White (1966:293) states their importance: 'These two letters contain the earliest and fullest pagan account of Roman conflict with Christians in the first century of their existence'. Since the apostolic introduction of the gospel, the churches had clearly spread. But where had Pliny come in contact with Christianity? During the course of his duties he had earlier mentioned three cities in his letters:

- Nicomedia (Ep. 37, 41, 49)

- $\operatorname{Nicea}(E p .39,63,77,81)$

- Sinope (Ep. 90).

The provenance for Letter 96 is unclear, but it is positioned between letters from Amisus (Ep. 92; cf. 110) and Amastris (Ep. 98, 100). Scholars are divided about its origin, but Sherwin-White (1966:694) prefers Amastris, because in the 2nd century it became the chief Christian centre of Pontus. ${ }^{17}$ Pliny had probably encountered Christians in all these cities, yet his problems with them surfaced only in Pontus and not in Bithynia. The urban thrust of this study agrees with a key line in Pliny's letter to Trajan, written around 110 AD, which seems to validate Stark's urban hypothesis. In Epistle 96.9 Pliny writes: 'It is not only the towns (civitates), but villages (vicos) and rural districts (agros) too which are infected through contact with this wretched cult' (Loeb transl.). Pliny is amazed at the distribution of this insidious movement in Pontus, not only in the cities, but also in the villages! $!^{18}$ Thus the movement from urban to rural has taken place in the decades since Christianity was introduced.

Caesarea Mazaca became an important bishopric in early church history. Gregory the Illuminator, the reputed founder of the Armenian Orthodox Church, was brought to the city as a child in $257 \mathrm{AD}$, where he was raised as a Christian and returned to Armenia to serve Tiridates' son. Basil the Great served as bishop of the city from 330-379 AD. Regarding Ancyra, Eusebius' reference (Hist.eccl. 5.16) to Montanists there is the only clear reference to Christians in the city before 200 AD. Paul most probably visited Dorylaeum on his second journey and it is here that he likely was forbidden to go northward to Nicea and Nicomedia in Bithynia (Ac 16:6-10; Wilson 2005:382-383). There is no further evidence of Christianity until the rise of Montanism in the late 2nd century. Montanist inscriptions have been recorded in Dorylaeum, but unfortunately these inscriptions had already disappeared when Cox and Cameron visited the city in 1931 (1937: xvii). At Nicomedia there is an Orthodox tradition concerning Prochorus, one of the original seven deacons (Ac 6:5; Bruce 1990:184). Prochorus is said to have traveled with Peter to Nicomedia, where he was appointed the first bishop of the church in the city.

All of the provinces mentioned in 1 Peter 1:1 had a Christian community by the end of the 1st century and many of the target cities had early traditions related to Christianity's arrival.

17.Describing the progression of these letters, Sherwin-White (1966:532) also states that apart from two awkward points, 'The serial order thus provides a consistent pattern for the journeys in a rational geographical order'. This suggests that there pattern for the journeys in a ration
was a similar order in 1 Peter $1: 1$.

18. For a radically different interpretation of this data, see Hopkins (1998:187-191). He concludes his discussion by stating: 'In my view, Pliny's account is either inaccurate and/or describing something atypical' (1998:191). 


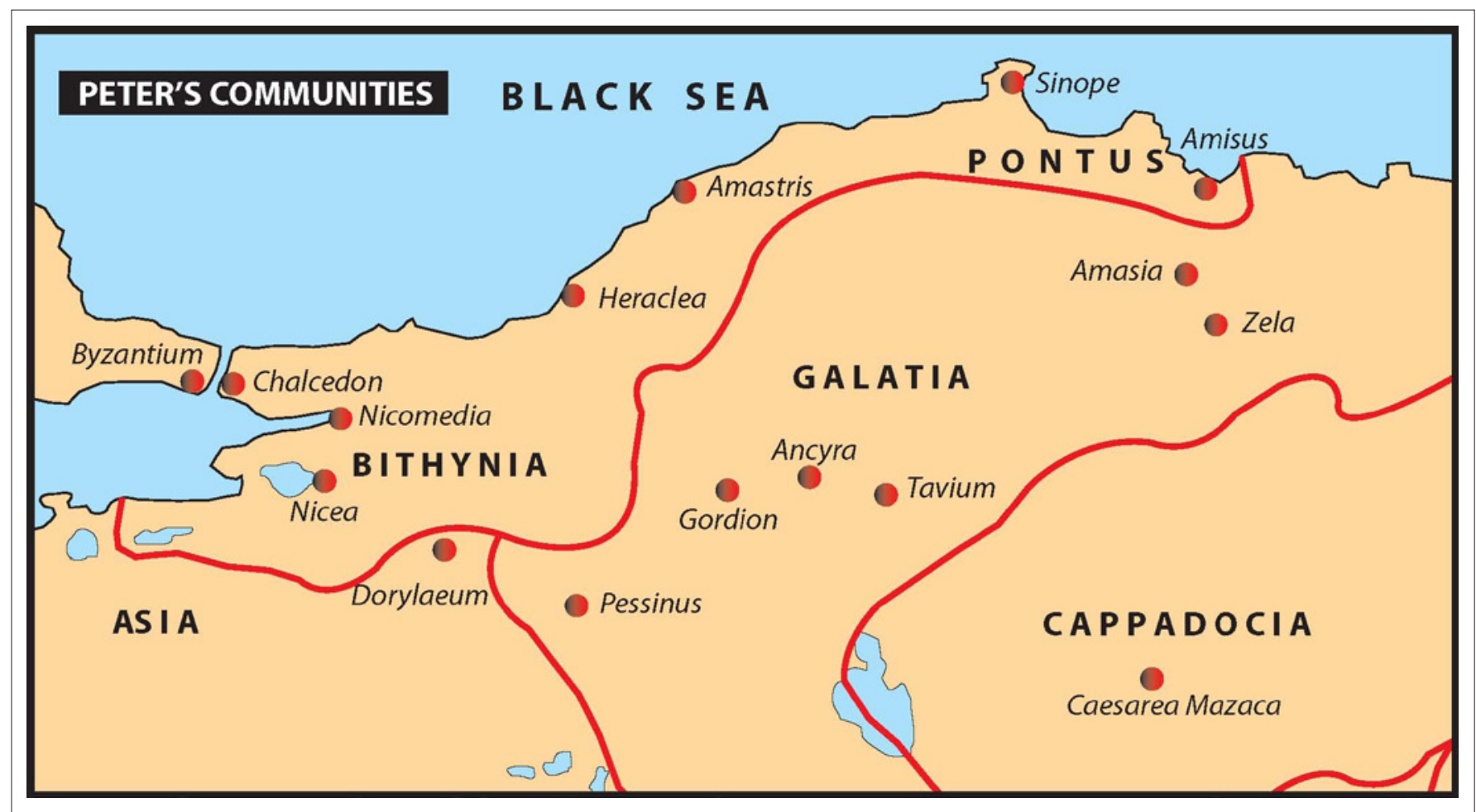

MAP 1: The geography of Peter's communities (prepared by Burhan Oral).

TABLE 3: The seven hypotheses and their applicability to the seven cities.

\begin{tabular}{|c|c|c|c|c|c|c|c|c|}
\hline Hypothesis & City & Sinope & Amisus & Ancyra & $\begin{array}{l}\text { Caesarea } \\
\text { Mazaca }\end{array}$ & Dorylaeum & Nicea & Nicomedia \\
\hline 1 & Accessibility to Jerusalem & $x$ & $x$ & $x$ & $x$ & $x$ & $x$ & $x$ \\
\hline 2 & Hellenic city & $x$ & $x$ & - & $x$ & $?$ & $x$ & $x$ \\
\hline 3 & Larger city & - & $x$ & $x$ & $x$ & - & - & $x$ \\
\hline $4 a$ & Port city & $x$ & $x$ & - & - & - & $x$ & $x$ \\
\hline $4 b$ & Cybele worship & $x$ & $x$ & $x$ & - & $x$ & $x$ & $x$ \\
\hline 5 & Isis worship & $x$ & $?$ & - & - & - & $?$ & $x$ \\
\hline 6 & Diaspora community & $x$ & - & - & $x$ & - & $x$ & $x$ \\
\hline 7 & Christian community & $x$ & $x$ & ? & $?$ & $x$ & $?$ & $x$ \\
\hline
\end{tabular}

X, Applicable; ?, Unknown.

Because there is no evidence of a Jewish community in half of these cities, Stark's hypothesis about this interrelationship remains unsubstantiated. An early Christian community is known to have existed in only two of the cities with a Jewish community.

\section{Conclusion}

Using some of Stark's hypotheses as a heuristic tool, it was investigated whether seven major cities of the five provinces mentioned in 1 Peter 1:1 might have been candidates to become host communities for early Christianity. A discussion of each factor has indeed suggested that these cities would be prime targets for the apostolic message to spread. All were either capitals or leading cities of their respective provinces and on important transportation routes easily accessible to Peter or other itinerant evangelists coming from Jerusalem or for a messenger travelling from Rome. Five were Hellenised in the centuries before Christ and four were port cities, accessible to international commerce. Diaspora Jewish communities are documented in each of the provinces, with the exception of Galatia. Traditions related to Christian activity are found in most of these cities by the 2nd century AD. Only the hypotheses related to the presence of Cybele and Isis temples appear to have little applicability because of the ubiquitous worship of these deities. The chart above synthesises the data $\mathrm{p}$ resented in this article. Research on these cities will continue, of course, but this investigation has revealed significant data that suggests Sinope, Amisus, Caesarea Mazaca, Ancyra, Dorylaeum, Nicea and Nicomedia most probably had Christian house churches that became the primary addresses in the provinces mentioned in 1 Peter 1:1.

\section{References}

Ameling, W., 2004, Inscriptiones Judaicae Orientis, Band II, Kleinasien, Mohr Siebeck, Tübingen.

Barsanti, C., 2003, 'The İnik-Nicea's archaeological museum: In search of a catalogue', in I. Akbaygil, H. Inalcık \& O. Aslanapa (eds.), Iznik through history, pp. 267-301, Turkiye Is Bankasi Kultur Yayinlari, Istanbul.

Bauckham, R.J., 1995, 'James and the Jerusalem church', in R. Bauckham (ed.), The book of Acts in its Palestinian setting, BAFCS vol. 4, pp. 415-480, Eerdmans, Grand Rapids.

Bekker-Nielsen, T., 2008, Urban life and local politics in Roman Bithynia, Aarhus, Aarhus University Press, viewed 23 July, 2010 from http://www.pontos.dk/ Aarhus University Press, viewed 23 July,
publications/ books/black- sea-studies-7 
Broughton, T.R.S., 1938, 'Roman Asia Minor' in T. Frank (ed.), An economic survey of ancient Rome, vol. 4, pp. 503-916, Johns Hopkins University Press, Baltimore.

Bruce, F.F., 1990, The Acts of the apostles, 3rd edn., Eerdmans, Grand Rapids.

Bruce, F.F., 1992, 'Travel and communication (NT world)', in D.N. Freedman (ed.), The anchor Bible dictionary, vol. 6, pp. 648-653, Doubleday, New York.

Bryer, A. \& Winfield, D., 1985, The Byzantine monuments and topography of the Pontos, Dumbarton Oaks, Washington, D.C.

Chandler, T. \& Fox, G., 1974, Three thousand years of urban growth, Academic, New York.

Chandler, T., 1987, Four thousand years of urban growth: an historical census, 2nd edn., Edwin Mellen, Lewiston, N.Y.

Claerhout, I. \& Devreker, J., 2008, Pessinous, Homer Books, Istanbul.

Cohen, G., 1996, Hellenistic settlements in Europe, the islands, and Asia Minor, University of California Press, Berkeley.

Cox, C.W.M. \& Cameron, A., 1937, Monuments from Dorylaeum and Nacolea, MAMA $\mathrm{V}$, University of Manchester, Manchester.

Elliott, J.H., 1981, A home for the homeless, Fortress, Philadelphia.

Elliott, J.H., 2000, 1 Peter, Doubleday, New York.

Fine, S. \& Rutgers, L.V., 1996, 'New Light on Judaism in Asia Minor', Jewish Studies Quarterly 3, 1-23.

Gates, C., 2003, Ancient cities: The archaeology of urban life in the ancient near eas and Egypt, Greece and Rome, Routledge, London.

Grant, M., 1997, A guide to the ancient world, New York, Barnes \& Noble.

Gruen, E.S., 2002, Diaspora, Harvard University Press, Harvard University.

Hachlili, R., 1998, Ancient Jewish art and archaeology in the Diaspora, Harvard University Press, Cambridge.

Hanfmann, G.M.A., 1983. Sardis from prehistoric to Roman times, Harvard University Press, Cambridge.

Hemer, C.J., 1978, 'The address of 1 Peter', Expository Times 89(8), 239-243. doi:10.1177/001452467808900805

Høfte, J.M., 2009, 'The administrative organization of the Pontic kingdom', in J.M.Høfte (ed.), Mithridates VI and the Pontic kingdom, pp.95-107, University of Aarhus, Aarhus, viewed 23 July 2010, from http://www.pontos.dk/publications/ books/bss-9-files/bss-9-05-hojte

Hopkins, K., 1998, 'Christian number and its implications', Journal of Early Christian Studies 6(2), 185-226. doi:10.1353/earl.1998.0035

Hort, F.J.A., 1898, First epistle of St. Peter I,1-II,17, Macmillan, London.

Jobes, K., 2005, 1 Peter, Baker, Grand Rapids.

Leafe, W., 1916, 'The commerce of Sinope', Journal of hellenic studies 36, 1-15. doi:10.2307/625746

Levinskaya, I.A., 1996, Diaspora setting, BAFCS vol. 5, Eerdmans, Grand Rapids.

Magie, D., 1950, Roman rule in Asia Minor, 2 vols., Princeton University Press, Princeton. doi:10.2307/500057

Magie, D., 1953, 'Egyptian deities in Asia Minor in inscriptions and on coins', American Journal of Archaeology 57(3), 163-187.

Meeks, W., 1981, The first urban Christians, Yale University Press, New Haven.
Michaels, J.R., 1988, 1 Peter, Thomas Nelson, Nashville.

Mitchell, S., 1982. The Ankara district: the inscriptions of north Galatia, RECAM II, B.A.R. International, Oxford.

Mitchell, S., 1992, 'Galatia', in D.N. Freedman (ed.), The anchor Bible dictionary, vol. 2 870-72, Doubleday, New York.

Mitchell, S., 1993, Anatolia, 2 vols., Oxford University Press, Oxford.

Mitchell, S., 2003, 'Nicomedia', in S. Hornblower \& A. Spawforth (eds.), The Oxford classical dictionary, p. 1043, Oxford University Press, Oxford.

Munro, J.A.R., 1901, 'Roads in Pontus, royal and Roman', Journal of hellenic studies 21 , 52-66. doi:10.2307/623865

Pascuiti, D. \& Chase-Dunn, C., 2002, Estimating the population sizes of cities, viewed 14 July 2010, from http://www.irows.ucr.edu/research/citemp/estcit/estcit.htm

Price, S.R.F., 1984, Rituals and power: The Roman imperial cult in Asia Minor, Cambridge University Press, Cambridge.

Ramsay, W.M., 1907, The cities of St. Paul, Hodder \& Stoughton, London.

Robinson, D., 1906a, 'Ancient Sinope, First Part', American journal of philology 27(2) 125-153. doi:10.2307/288823

Robinson, D., 1906b, 'Ancient Sinope Second Part', American journal of philology 27(3), 245-279. doi:10.2307/288591

Roller, L., 1999, In search of God the mother, University of California Press, Berkeley.

Seland, T., 2005, Strangers in the light: Philonic perspectives on Christian identity in 1 Peter, Brill, Leiden.

Sherwin-White, A.N., 1966, The letters of Pliny: a social and historical commentary, Oxford University Press, Oxford.

Smallwood, E.M., 1981, The Jews under Roman rule, Brill, Leiden.

Stark, R., 1997, The rise of Christianity, HarperSanFrancisco, San Francisco.

Stark, R., 2007, Cities of God, HarperSanFrancisco, San Francisco.

Talbert, C. (ed.), 2000, The Barrington atlas of the classical world, Princeton University Press, Princeton.

Trebilco, P.R., 1991, Jewish communities in Asia Minor, Cambridge University Press, Cambridge. doi:10.1017/СBO9780511520464

Tsetskhladze, G.R., 2007, 'Greeks and locals in the southern Black Sea littoral: A reexamination', in G. Herman \& I. Shatzman (eds.), Greeks between east and west: essays in Greek literature and history in memory of David Asheri, pp. 160-195, The Israel Academy of Sciences and Humanities, Jerusalem.

Turcan, R., 1996, The cults of the Roman Empire, Blackwell, Oxford

Van der Horst, P., 1990, 'Juden und Christen in Aphrodisias im Licht ihrer Beziehungen in anderen Städten Kleinasiens', in J. van Amersfoort \& J. van Oort (eds.), Juden und Christen in der Antike, pp. 125-143, Kok, Kampen.

Wilson, D.R., 1960, 'The historical geography of Bithynia, Paphlagonia and Pontus in the Greek and Roman periods', B.Litt. thesis, Oxford.

Wilson, M., 2001, 'Early Christianity in the Black Sea region', paper presented at the Second International Congress on Black Sea Antiquities, Bilkent University, Ankara, Turkey, 2001.

Wilson, M., 2005, 'The trajectory of early Christianity in Dorylaeum and its environs', in O. Beklan, A. Oğuz \& E. İznik (eds.), I. International Symposium on Eskişehir Throughout History, pp. 381-388, Anadolu Üniversitesi Yayınları, Eskişehir. 